\begin{tabular}{|l|l|l|}
\hline \multicolumn{2}{|c|}{ PublisherInfo } \\
\hline \hline PublisherName & $:$ & BioMed Central \\
\hline \hline PublisherLocation & $:$ & London \\
\hline \hline PublisherImprintName & $:$ & BioMed Central \\
\hline \hline
\end{tabular}

\title{
Zinc finger nucleases correct genes
}

\begin{tabular}{|l|l|l||}
\hline \multicolumn{2}{|c||}{ ArticleInfo } \\
\hline \hline ArticleID & $:$ & 5075 \\
\hline \hline ArticleDOI & $:$ & $10.1186 /$ gb-spotlight-20050404-01 \\
\hline \hline ArticleCitationID & $:$ & spotlight-20050404-01 \\
\hline \hline ArticleSequenceNumber & $:$ & 51 \\
\hline \hline ArticleCategory & $:$ & Research news \\
\hline \hline ArticleFirstPage & $:$ & 1 \\
\hline \hline ArticleLastPage & $:$ & 4 \\
\hline \hline & & RegistrationDate : 2005-4-4 \\
ArticleHistory & $:$ & OnlineDate \\
\hline \hline ArticleCopyright & $:$ & BioMed Central Ltd2005-4-4 \\
\hline \hline ArticleGrants & $:$ & \\
\hline \hline ArticleContext & $:$ & 130596611 \\
\hline \hline
\end{tabular}




\section{Graciela Flores}

Email: graciela_flores@nasw.org

Using engineered zinc-finger nucleases - DNA-binding proteins that target specific sequences researchers at a biotechnology company report this week in an advanced online publication in Nature that they have achieved the highest levels of permanent targeted gene correction in cultured human cells described to date.

Michael Holmes and his colleagues at Richmond, Ca. - based Sangamo Biosciences corrected a defective version of the IL2R-gamma receptor gene, which is mutant in children with X-linked severe combined immunodeficiency. Sangamo had used zinc-finger proteins before in several instances, among them, to inhibit specific single gene expression in vivo.

"With our technology platform here at Sangamo, we can basically engineer zinc-finger proteins to recognize virtually any sequence," Holmes, the senior author of the study, told The Scientist. "Here, we show that gene correction can be done at a specific site of the genome, where a mutation occurs, and at high frequency."

The authors report that more than $18 \%$ of the cells were correctly modified without selection, of which $7 \%$ acquired the desired modification in both chromosomes.

"This is the highest level of gene targeting I've seen," said Dana Carroll of the University of Utah, who described the paper as "terrific." Recent estimateshave found an absolute rate of gene targeting in human cells of 3 to $5 \%$.

According to Carroll, the key for the researchers' success was their ability to introduce a break in the desired gene. "Normally, gene targeting is done by isolating and manipulating a segment of the gene in the laboratory, and then putting it back into cells, hoping that homologous recombination will lead to the replacement of the endogenous gene with this manipulated gene," explained Carroll. "The problem is that the frequency of that sort of gene targeting is typically quite low - about one in a million cells gets the targeting event."

Sangamo's strategy built upon two fundamental observations previously made by other researchers: that a double-strand break stimulates homologous recombination at a target and that such breaks can be made with designed zinc-finger nucleases.

Although other researchers had been successful at targeting specific sequences, no one had designed the zinc-finger protein nucleases from scratch, Srinivasan Chandrasegaran of Johns Hopkins University, who did not participate in the study, told The Scientist.

"Carroll modified a zinc-finger protein that we gave them to target a desired gene, and they showed that it worked," said Chandrasegaran, "but no one had done it in an endogenous human gene."

"I think it's only a matter of time before it's applied therapeutically, in ex vivo gene therapy," Chandrasegaran said. 
According to Carroll, who was not involved in the research, what is most impressive is that the authors were able to make nucleases that were highly specific for the human target. This was a double challenge of design - "making a set of zinc-fingers that will bind to a chosen target sequence, and making the zinc-fingers specific enough to cut the target but not to make a lot of other breaks elsewhere in the genome." The authors apparently succeeded in meeting both aspects of the challenge, Carroll said.

"Our approach is in fundamental contrast to previous approaches in that we can go in and literally edit a gene that's already in the patient, leaving it corrected, but still controlled by its normal promoter," said Sangamo President and Chief Executive Officer Edward Lanphier. He said the approach avoids the need for integration of foreign viral DNA into the genome and thus eliminates the dangers of possible mutations due to transgene silencing, improper activity, or misintegration, which have caused leukemias in gene therapy patients in the past. "We believe that this permanent correction can ultimately lead to successful outcomes," Lanphier told The Scientist.

"We are moving forward in several other projects, trying to target other genes responsible for monogenic disorders and also trying to make alterations to knock out genes," said Holmes. This might have therapeutic benefits in genes such as those that encode the receptors that HIV virus uses to enter T cells."

\section{References}

1. L. Pray, "A finger on the pulse of transcriptional control," The Scientist, 17:33, July 14, 2003., [http://www.the-scientist.com/2003/7/14/33/1]

2. A. Constans, "Transcription by design," The Scientist, November 18, 2004., [http://www.thescientist.com/2004/11/8/30/1]

3. F.D. Urnov et al., "Highly efficient endogenous human gene correction using designed zinc-finger nucleases," Nature, DOI:10.1038/nature03556, April 3, 2005., [http://www.nature.com]

4. Sangamo Biosciences, [http://www.sangamo.com/index.php]

5. C. Holding, "Fingering single genes," The Scientist, September 23, 2003., [http://www.thescientist.com/news/20030923/03]

6. Dana Carroll, [http://www.bioscience.utah.edu/mb/mbFaculty/carrollDana/carrollDana.html] 
7. M.H. Porteus, D. Baltimore, "Chimeric nucleases stimulate gene targeting in human cells," Science, 300:763, May 2, 2003.

8. Srinivasan Chandrasegaran, [http://commprojects.jhsph.edu/faculty/ detail.cfm 2 id $=323 \&$ Lastname $=$ Chandrasegaran $\&$ Firstname $=$ Srinivasan $]$

9. J.P. Roberts, "Gene therapy's fall and rise (again)," The Scientist, 18:22, September 27, 2004. , [http://www.the-scientist.com/2004/09/27/22/1] 